\title{
Peertechz
}

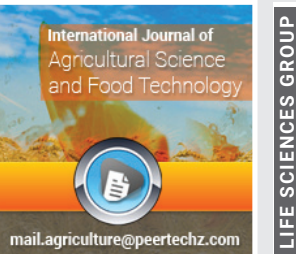

Research Article

\section{Evaluation and participatory variety selection of improved highland sorghum varieties for smallholder farm at west hararghe zone}

\section{Temesgen Begna* and Hailu Gichile}

Ethiopian Institute of Agricultural Research, Chiro National Sorghum Research and Training Center P. O. Box 190, Chiro, Ethiopia
Received: 25 November, 2021

Accepted: 23 December, 2021

Published: 24 December, 2021

*Corresponding author: Temesgen Begna, Ethiopian Institute of Agricultural Research, Chiro National Sorghum Research and Training Center P. O. Box 190, Chiro, Ethiopia, Tel: +251921196966;

E-mail: tembegna@gmail.com

ORCID: https://orcid.org/0000-0001-5937-4072

Keywords: Farmers preference; Selection criteria; Adoption; Integrated breeding; Improved varieties Sorghum

Copyright License: (C) 2021 Begna T, et al. This is an open-access article distributed under the terms of the Creative Commons Attribution License, which permits unrestricted use, distribution, and reproduction in any medium, provided the original author and source are credited.

https://www.peertechzpublications.com

\section{Abstract}

Participatory variety selection is the most important breeding program which enhanced the adoption of improved varieties through creating awareness based on smallholder farmers' selection criteria. Several different improved sorghum varieties are released at different international and national research institutions at different times, however, the technologies were not properly addressed the farmers based on participatory, client oriented and demand driven. The experiment was carried out in West Hararghe Zone; Oromia Regional State, Ethiopia with the objective to identify and recommend the best adapted and performed improved sorghum varieties with farmers' preference traits through continuous performance evaluation at different stages of the sorghum. A total of six sorghum varieties were evaluated in randomized complete block design in the 2019 main cropping season. Farmers have evaluated the entire experimental units using different statistical tools like direct-matrix and pair-wise ranking algorithms at maturity stage. Farmers set selection criteria to identify the superior improved varieties as compared to the local check by listing different agronomic traits like yield, biomass, seed color, seed size and biotic and abiotic resistance. The analysis of variance showed that there was highly significant difference $(\mathrm{p}<0.01)$ among the genotypes for all studied traits. The greatest grain yield was recorded from the variety Dibaba $\left(11325 \mathrm{Kgha}^{-1}\right)$ and $\mathrm{Jiru}\left(10200 \mathrm{Kgha}^{-1}\right)$ respectively. Likewise, based on the overall farmer's preference, Dibaba and Jiru were ranked first and second and followed by Adelle, ETS2752 and Chiro respectively. Additionally, the study revealed that participatory varietal selection is playing decisive role in gathering farmers' perceptions, preferences, merits and shortcomings of sorghum varieties for future improvement. Hence, based on the result of the study, variety Dibaba and Jiru were recommended for multiplication and distribution to farmers through both formal and informal seed systems. Generally, the integration of plant breeders and farmers' perceptions are used to increase the adoption rate and design a good breeding program for future improvement.

\section{Introduction}

Sorghum [Sorghum bicolor (L.) Moench; $2 \mathrm{n}=20$ ] is the $5^{\text {th }}$ most important cereal crop in the world [1] and the $2^{\text {nd }}$ major crop (after maize) across all agro-ecologies in Africa [1]. It is originated in the Eastern quadrant of Africa, particularly in Ethiopia where the largest genetic diversity is available [2]. Sorghum has the largest genetic diversity and has domesticated with wide ranges of collections in various agro-ecologies of Ethiopia [3]. Sorghum stands third in Ethiopia in terms of area coverage after teff and maize and second next to maize in terms of productivity [4]. Sorghum is grown globally for food purposes in dryland agriculture and has wider adaptability to drought prone areas. The excellent drought tolerance characteristic of sorghum is very critical for the adaptation to where other crops can least survive. Sorghum is playing a remarkable role in addressing the problem of food insecurity and meeting the increasing world food demand. Sorghum is grown globally for food and feed purposes in dry land agriculture because of its wider adaptability to drought-prone areas [5]. Sorghum is supporting the lives of millions of people across the world and particularly in developing countries and is a staple food crop in moisture stressed areas [6]. 
Sorghum is primarily used as a food crop particularly in developing countries [7] and the improvement has been made food and nutritional security [8]. Currently, the demand for food is increasing alarmingly due to climate change and population growth. Therefore, sorghum is expected to play pivotal role to address the growing demand of world population and is preferred crop in areas where other crops are affected by drought [9]. Most importantly, developing new sorghum varieties is the key alternatives for the adaptation of agriculture to climate change. The adaptation of improved sorghum varieties to climate change needs more complementary strategies to develop new superior sorghum varieties to make resilient to climate change within the current footprint.

Participatory variety selection is the research process by which farmers are routinely involved in selecting varieties to prefer the desirable traits in order to increase the adoption rate of superior and stable varieties. In participatory variety selection, farmers are involved with the opportunities to make the decision in selecting the best performing varieties based on the key criteria of their desirable traits. Farmers' involvement in participatory variety selection can take many advantages, which include defining breeding goals and priorities, selecting the best varieties on their farm for further improvement, designing and planning for the following activities through discussing with scientists, suggesting methodological changes and multiplying the seed of preferred improved varieties.

Generally, participatory variety selection is the engagement of farming communities in higher and complex manner to make decision at early and fundamental stages of the variety development chain [10]. Understanding farmers' preferences across different agro-ecologies and growing seasons is an important and first step for breeding programs that seek to develop acceptable varieties by farmers [11]. Participatory variety selection involves a mixture of breeders, farmers, scientists and other stakeholders in variety development [12]. The participatory variety selection is supporting the improvement of local landraces with optimal agronomic practices and evaluates the finished breeding materials on farmers' fields [13]. The new improved varieties are released without farmers' preferences and the process is typically supply-driven rather than demand driven. But, participatory variety selection has reversed the processes to demand-driven, because the supply-driven developed varieties are not adopted [14].

Therefore, the complex nature of agricultural research demands integrated efforts among farmers, researchers and extensionist to develop suitable improved sorghum varieties with desired qualities [15]. Participatory variety selection is increasing adoption of suitable improved varieties in order to meet the growing demands of farmers toward improved varieties and enhancing skills in variety developing processes with desirable traits [11]. Participatory varietal selection is playing a key role in identifying farmers preferred improved varieties effectively and is offering the long-last solution to the constraints which cause farmers to grow low yielding, vulnerable to biotic and abiotic stresses land-races [16]. Participatory variety selection is providing substantial opportunities to communities to evaluate and select the best performed varieties with desirable traits in their own fields Participatory variety selection is enhancing the accessibility of improved sorghum varieties to farmers, ensuring food security, increasing genetic diversity, help to extend the released varieties and enhance adoption rates in large scale, selecting varieties at cost-effectiveness and producing and scaling up at the community level [17].

The sorghum improvement programs are continuously developing several improved sorghum varieties with little or no involvement of farmers' participation for demand driven technology development. This is mainly due to the limitation of selection criteria of researchers to a few traits which do not represent farmer's selection traits. Therefore, there is a demand to produce improved sorghum varieties adapted to different growing seasons and agro-ecologies with smallholder farmers' selection criteria [18]. Apart from the significant importance of sorghum to ensure food and nutritional security in the country in general and in the study area in particular, smallholder farmers were not aware of the presence of superior improved sorghum varieties for their agro-ecologies.

Therefore, smallholder farmers are still producing low yielding land-races, long-maturing and susceptible to biotic and abiotic stresses. Thus, the utilization of improved sorghum varieties (lack of farmers preferred high yielding sorghum varieties, early maturing, better quality, diseases and pests) is very low in the target areas. This also caused the low adoption of improved sorghum variety due to poor participation of farmers' in the varietal selection process, inadequate knowledge of the farmers about the varieties, lack of improved variety that adapts the specific environments and inadequate supply of seed of the varieties to satisfy farmers' needs, inadequate research interventions, lack of improved varieties that give reasonable yield under farmers' cultural management, and poor researchextension-farmer linkage [19].

Nowadays, the development of superior improved sorghum varieties for different agronomic traits highly required breeder's particular attention. As the human population is increasing geometrically, the yield should be increased in parallel to address the food insecurity problems. For increasing the productivity and adoption of new varieties, the integration of breeders and farmers should be tightened. Hence, the demand for improved and preferred sorghum varieties is increasing from time to time. Therefore, participatory variety selection is crucial in understanding farmers' selection criteria, increasing awareness and adoption of improved varieties. The development of locally adapted improved sorghum varieties to a particular environment is one solution to overcome the challenges of both local adaptation and local farmers' end user requirements. Therefore, the objectives of this study were to evaluate and identify the adapted and farmers preferred improved sorghum variety/es and design a good breeding program for future improvement.

\section{Materials and methods}

\section{Location of the experiment}

The study was undertaken in the eastern part of Ethiopia 
specifically in West Hararghe zone of Oromia National Regional State. Both Hirna and Doba testing locations represent the high land sorghum growing environments of the zone. The experiment was implemented during the 2019 main cropping season and the locations were described as below (Table 1).

\section{Plant genetic materials}

Five regionally and nationally released sorghum varieties and a local check were evaluated in 2019 during the main cropping seasons at both testing sites. The improved sorghum varieties were developed for the highland agro-ecologies in different times. The genetic materials were evaluated for pros of high performance in adaptation, yield and resistance to biotic and abiotic stresses, biomass and other quality traits Table 2.

\section{Experimental design and trial management}

The experiment was carried out in a randomized completely block design with two replications to evaluate the varieties. Each variety was planted on a plot size of $15 \mathrm{~m}^{2}$ ( $5 \mathrm{~m}$ length by $3 \mathrm{~m}$ width), with an intra- and inter-row spacing of 0.20 and $0.75 \mathrm{~cm}$, respectively. During planting, the seeds were manually drilled at the seed rate of $12 \mathrm{kgha}^{-1}$ and thinning was done after 20 days of emergence. All the recommended management practices with the recommended fertilizer rates of $100 \mathrm{kgha}^{-1}$ NPS was applied to the basal at the time of planting whereas $50 \mathrm{kgha}^{-1}$ Urea was applied in the form of split application, half of which was applied together with NPS during planting and the remaining top dressed before heading at knee stage. Weeds were controlled manually and pests were controlled using recommended chemicals.

\section{Data collection}

Phenotypic data on quantitative traits were collected on a plant and plot basis [20].

Days to flowering (DTF): Number of days from emergence till $50 \%$ of the plants in a plot showed flowering halfway down the panicle.

Table 1: Description of the Experimental Location

\begin{tabular}{|c|c|c|c|c|c|c|c|}
\hline Location & $\begin{array}{c}\text { Altitude } \\
(\mathbf{m a s})\end{array}$ & $\begin{array}{c}\text { Rainfall } \\
(\mathbf{m m})\end{array}$ & $\begin{array}{c}\text { Temp } \\
\left.\mathbf{(}^{\circ} \mathbf{C}\right) \text { Min }\end{array}$ & Max & Latitude & Longitude & Soil type \\
\hline Hirna & 1,763 & 950 & 16.00 & 24.00 & $9^{\circ} 12^{\prime} \mathrm{N}$ & $41^{\circ} 4^{\prime} \mathrm{E}$ & $\begin{array}{c}\text { Black } \\
\text { Vertisols }\end{array}$ \\
\hline Doba & 2200 & 750 & 18.00 & 26.00 & $9^{\circ} 30^{\prime} \mathrm{N}$ & $4^{4} 1^{\circ} 15^{\prime} \mathrm{E}$ & $\begin{array}{c}\text { Black } \\
\text { Vertisols }\end{array}$ \\
\hline
\end{tabular}

Table 2: Sorghum varieties included in farmers' group variety evaluation experiment during 2019.

\begin{tabular}{|c|c|c|c|c|c|}
\hline S. N & Variety & Agro-ecology & Releasing year & Yield tha $^{-1}$ & Color \\
\hline 1 & ETS2752 & Highland & 1978 & $3.0-5.5$ & White \\
\hline 2 & Chiro & Highland & 1998 & $4.2-5.8$ & Red \\
\hline 3 & Dibaba & Highland & 2015 & $3.7-5.0$ & Brown \\
\hline 4 & Jiru & Highland & 2016 & $3.3-8.6$ & Brown \\
\hline 5 & Adelle & Highland & 2016 & $3.7-7.2$ & White \\
\hline 6 & Shafare & Highland & Local (check) & low & Red \\
\hline
\end{tabular}

Source: Melkassa miscellaneous year's variety release documents (2018)
Plant height (PH in $\mathbf{c m}$ ): The height of the plant from the bottom to the tip of the panicle during flowering on 5randomly tagged plants.

Days to maturity (DTM): The number of days from emergence to the date when $95 \%$ of the plants matured physiologically.

Disease reaction (score): Disease severity [1-5], was recorded from each plot during different growth stages of plants.

Grain yield (GY): Grain yield obtained from the total harvest of the plot and then converted to ton/ha after adjusting to optimum seed moisture content.

Thousands seed weight (TSW in g): The weight of 1000 grains sampled from a plot at $12.5 \%$ moisture content recorded in gram.

\section{Qualitative data collected}

Seed color: $1=$ White, $2=$ Red, $3=$ Gray, $4=$ brown, Seed size: $1=$ Big, $2=$ Medium, $3=$ Small

\section{Statistical data analysis}

Analysis of variance (ANOVA) was performed using statistical package version 9.4 [21], for combined analysis over locations and means separated using LSD (Least Significant Difference) at the $5 \%$ probability level.

\section{Farmers Participatory Varietal Selection (PVS)}

Participatory variety selection was done at maturity using participatory tools like pair wise ranking methods. A total of eighty-one farmers (male $=55$ and female $=26$ ) participated to evaluate and select improved sorghum varieties using participatory tools during the 2019 cropping seasons at both locations. Both male and female key informant farmers were randomly selected and participated regardless of their religion and wealth to determine the performance of sorghum improved technologies. Male and female informants were assembled and they prioritized their selection criteria and jointly agreed on five characters (grain yield, biomass, resistance to biotic stresses, seed size and color) during the maturity stage.

Farmers identified their best selection criteria and carefully observed the entire experimental plots to select their fitness to the specific criteria according to the existing constraints and opportunities in their micro-environments. The assignments of ranks to each variety and traits were determined from the number of times each selection criterion was preferred by the group [22]. The ranking procedure was explained for farmer participants and then each selection criterion was ranked and scored on a scale of 1-5 (5= Excellent, 4= Very good, 3= Good, 2= Poor and $1=$ Very poor). During the evaluation, all farmers have selected varieties with their trait of interest. All the selected characters were tabulated in a matrix scoring method and pair wise fashion was used to compare each selection criteria. The farmers' own selection criteria were analyzed using the pair-wise ranking matrix (Table 3 ). The best adapting and 
performing sorghum varieties was identified based on a simple ranking score method (Tables 4,5).

\section{Results and discussion}

\section{Analyses of Variance (ANOVA)}

The analyses of variances revealed significantly high differences $(p<0.01)$ among the genotypes for all of the quantitative characters (Table 6). The combined analysis of variance revealed that varieties performed significantly different at $\mathrm{P} \leq 0.01$ for days to $50 \%$ flowering, plant height $(\mathrm{cm})$, days to maturity, grain yield $\left(\mathrm{kgha}^{-1}\right)$ and thousand seed weight (g) for combined locations. The presence of significant differences among sorghum genotypes for the studied traits ensured the presence of large genetic variation to be improved through simple selection. This indicated the presence of considerable variation in the studied genetic materials for these traits and improvement of the genotypes with these traits is possible with a simple selection. Plant breeding is primarily depending on the presence of substantial genetic variation to address the maximum genetic yield potential of the crops and exploitation of this variation through effective selection for further improvement. Hence, the obtained results encourage the availabilities of substantial genetic variation among sorghum genotypes for the studied traits.

\section{Mean performance of highland sorghum genotypes}

The superior sorghum varieties were identified based on the mean performance for different characteristics as indicated in (Table 7). The mean grain yield for genotypes ranged from

Table 3: Pair-wise ranking of farmers selection criteria at maturity stages during 2019.

\begin{tabular}{|c|c|c|c|c|c|c|c|c|}
\hline No & Selection criteria & GY & PHT & GC & DR & GS & Score & Rank \\
\hline 1 & GY & X & & & & & 5 & 1 \\
\hline 2 & PHT & GY & X & & & & 4 & 2 \\
\hline 3 & GC & GY & PHT & X & & & 2 & 4 \\
\hline 4 & DR & GY & DR & GC & X & & 3 & 3 \\
\hline 5 & GS & GY & PHT & GS & DR & X & 2 & 4 \\
\hline
\end{tabular}

Where: GY: Grain Yield; GS: Grain Size; GC: Grain Color; DR: Disease Resistance.

Table 4: Direct matrix ranking evaluation of genotypes by a group of farmers during 2019.

\begin{tabular}{|c|c|c|c|c|c|c|}
\hline $\begin{array}{c}\text { Selection } \\
\text { criteria }\end{array}$ & $\begin{array}{c}\text { Grain } \\
\text { yield }\end{array}$ & $\begin{array}{c}\text { Plant } \\
\text { height }\end{array}$ & $\begin{array}{c}\text { Grain } \\
\text { size }\end{array}$ & $\begin{array}{c}\text { Disease } \\
\text { resistance }\end{array}$ & $\begin{array}{c}\text { Total } \\
\text { score }\end{array}$ & Rank \\
\hline $\begin{array}{c}\text { Relative } \\
\text { weight }\end{array}$ & 5 & 4 & 3 & 3 & & \\
\hline ETS275 & $15(3)$ & $12(3)$ & $6(2)$ & $9(3)$ & 42 & 5 \\
\hline Chiro & $15(3)$ & $12(3)$ & $6(2)$ & $12(4)$ & 45 & 4 \\
\hline Jiru & $25(5)$ & $16(4)$ & $12(4)$ & $12(4)$ & 65 & 2 \\
\hline Adelle & $20(4)$ & $16(4)$ & $9(3)$ & $12(4)$ & 57 & 3 \\
\hline Dibaba & $25(5)$ & $20(5)$ & $12(4)$ & $15(5)$ & 72 & 1 \\
\hline Shafare (local) & $10(2)$ & $12(3)$ & $6(2)$ & $6(2)$ & 34 & 6 \\
\hline
\end{tabular}

Notice: The performance rating value of each variety given from 1-5 (5=excellent, $4=$ very good, 3 =good, $2=$ poor and $1=$ very poor) and which was obtained by multiplying the relative weight of each selection criteria with that of the performance rating number in the parenthesis.
Table 5: Farmers pair-wise ranking of evaluated highland sorghum genotypes during 2019

\begin{tabular}{|c|c|c|c|c|c|c|c|c|}
\hline Varieties & ETS275 & Chiro & Jiru & Adelle & Dibaba & $\begin{array}{c}\text { Shafare } \\
\text { (local) }\end{array}$ & Score & Rank \\
\hline ETS275 & $\mathrm{x}$ & & & & & & 1 & 5 \\
\hline Chiro & Chiro & $\mathrm{x}$ & & & & & 2 & 4 \\
\hline Jiru & Jiru & Jiru & $\mathrm{x}$ & & & & 4 & 2 \\
\hline Adelle & Adelle & Adelle & Jiru & $\mathrm{X}$ & & & 3 & 3 \\
\hline Dibaba & Dibaba & Dibaba & Dibaba & Dibaba & $\mathrm{X}$ & & 5 & 1 \\
\hline $\begin{array}{c}\text { Shafare } \\
\text { (local) }\end{array}$ & ETS275 & Chiro & Jiru & Adelle & Dibaba & X & 0 & 6 \\
\hline
\end{tabular}

Table 6: Analysis of variance (ANOVA) of measured agronomic traits during 2019.

\begin{tabular}{|c|c|c|c|c|c|c|}
\hline $\begin{array}{c}\text { Source of } \\
\text { variation }\end{array}$ & DF & DTF & DTM & PHT & GY & TSW \\
\hline Replication & 1 & $2.08^{\text {ns }}$ & $1.33^{\text {ns }}$ & $2.08^{\text {ns }}$ & $233802.08^{\text {ns }}$ & $3.00^{\star}$ \\
\hline Varieties & 5 & $122.08^{\star \star}$ & $517.13^{\star \star}$ & $96.08^{\star \star}$ & $16429552.08^{\star \star}$ & $30.53^{\star \star}$ \\
\hline Error & 5 & 1.28 & 4.93 & 7.68 & 45302.08 & 0.40 \\
\hline Mean & & 129.08 & 187.17 & 346.42 & 7552.08 & 36.83 \\
\hline CV (\%) & & 0.88 & 1.19 & 0.80 & 2.82 & 1.72 \\
\hline
\end{tabular}

$\star, \star \star$ - significant at $5 \%$ and $1 \%$ level respectively, ns $=$ non-significant at $5 \%$ probability level where, DTF: Days to 50\%Flowering; DTM: Days to physiological maturity; PHT: Plant Height; TSW: Thousand Seed Weight; GY: Grain Yield

Table 7: Mean values of different sorghum varieties for grain yield and other agronomic characters.

\begin{tabular}{|c|c|c|c|c|c|}
\hline & & Mean & & & \\
\hline Varieties & DTF & DTM & PHT & YLD & TSW \\
\hline Adelle & $123^{\mathrm{c}}$ & $172.5^{\mathrm{d}}$ & $347^{\mathrm{a}}$ & $8375^{\mathrm{c}}$ & $38 \mathrm{~b}^{\mathrm{c}}$ \\
\hline Chiro & $133.5^{\mathrm{b}}$ & $192.5^{\mathrm{b}}$ & $353^{\mathrm{a}}$ & $5825^{\mathrm{d}}$ & $36.5^{\mathrm{cd}}$ \\
\hline Dibaba & $121.5^{\mathrm{c}}$ & $181^{\mathrm{c}}$ & $348^{\mathrm{a}}$ & $11375^{\mathrm{a}}$ & $42^{\mathrm{a}}$ \\
\hline ETS2752 & $131.5^{\mathrm{b}}$ & $185.5^{\mathrm{c}}$ & $350^{\mathrm{a}}$ & $5315^{\mathrm{d}}$ & $35^{\mathrm{d}}$ \\
\hline Jiru & $123.5^{\mathrm{c}}$ & $175^{\mathrm{d}}$ & $347.5^{\mathrm{a}}$ & $10175^{\mathrm{b}}$ & $39^{\mathrm{b}}$ \\
\hline Shafare & $141.5^{\mathrm{a}}$ & $216.5^{\mathrm{a}}$ & $333^{\mathrm{b}}$ & $4250^{\mathrm{e}}$ & $30.5^{\mathrm{e}}$ \\
\hline Mean & 129.08 & 187.17 & 346.42 & 7552.08 & 36.83 \\
\hline LSD & 2.9121 & 5.7095 & 7.1254 & 547.13 & 1.6258 \\
\hline CV (\%) & 0.88 & 1.19 & 0.80 & 2.82 & 1.72 \\
\hline
\end{tabular}

Means in the same column followed by the same letters are not significantly different at $5 \%$ level of significance according to least significant difference (LSD); DTF: Days to $50 \%$ flowering; DTM: Days to physiological maturity; PHT: Plant Height; TSW: Thousand Seed Weight; GY: Grain Yield (Kg/ha).

4.275 tha t $^{-1}$ to 11.325 tha $^{-1}$. The grain yields obtained from Dibaba (11.325 tha ${ }^{-1}$ ) and Jiru (10.200 tha $\left.{ }^{-1}\right)$ were higher as compared to the other tested varieties and had yield advantages of $265 \%$ and $239 \%$ over local check $\left(4.275\right.$ tha $\left.^{-1}\right)$, respectively. The highest yield was obtained from Dibaba variety (11.325 tha $\left.{ }^{-1}\right)$, followed by Jiru (10.200 tha $\left.{ }^{-1}\right)$, Adelle (8.175 tha-1), ETS2752 (6.075 tha$\left.{ }^{1}\right)$, Chiro (5.775 tha-1), Shafare $\left(4.275\right.$ tha $\left.^{-1}\right)$. This implied that the performance of the Dibaba variety was highest as compared to the rest varieties whereas the local variety (Shafare) was the lowest for yield trait.

The superiority of the improved sorghum varieties over the check variety in grain yield indicates the potential positive economic advantage of improved sorghum varieties in the diverse sorghum-growing environments. Adelle (175 days),

Citation: Begna T, Gichile H (2021) Evaluation and participatory variety selection of improved highland sorghum varieties for smallholder farm at west hararghe zone. J Agric Sc Food Technol 7(3): 374-380. DOI: https://dx.doi.org/10.17352/2455-815X.000135 
Jiru (176 days) and Dibaba (180 days) varieties were stood first in maturing traits whereas Shafare (local) (213.50 days) variety was the longest maturing genotypes. Days to flowering and maturity are among the most important attributes that need to be considered in selecting varieties when and where the shortage of rainfall is a limiting factor for further improvement of yield and yield related traits. However, the shortage of rainfall is not a common and critical factor for highland areas. Both early and late maturing genotypes had the same grain fill duration, However, variation was detected for grain yield and related yield components among these genotypes, indicating the variation in the other attributes might be associated with factors other than the duration of grain fill.

The top yielder genotypes (Dibaba) required 119.5 days to flower and 180 days to mature which was close to the average for genotypes, 125.17 days for flowering and 186.33 days for maturity. This indicates that the yielding potential is not necessarily associated with crop phenology provided that genes for high yield potential are incorporated in the genotypes. The Dibaba variety showed superior mean performance in thousand seed weight(41.50g), which had direct proportional with yield and very important in vigorisity and germination.

\section{Participatory variety selection}

Participatory variety selection was conducted to identify and select farmers who preferred improved sorghum varieties with the desirable traits. The top-down approach has not been able to convince the farmers to grow improved sorghum varieties particularly in marginal areas. The farmers' selection criteria for improved varieties were not adequately assessed and well documented especially in Ethiopia. Hence, the majority of farmers still choose to grow older local varieties due to farmers' selection traits are multivariate in nature and small farmers consider multiple traits to satisfy their diverse needs. Farmers have been set their own criteria to evaluate and identify suitable varieties based on the available opportunities and constraints in the environments. Among the studied quantitative and qualitative traits, farmers have put the criteria to prefer improved varieties were grain yield, disease resistance, grain size and color.

Hence, the participatory varietal selection is the basic means of addressing the problems that cause farmers to grow low yielding old or obsolete varieties, cultivating diseasesusceptible and long-maturing local landraces. Participatory variety selection focuses on the facilitation and collaboration between plant breeders and farmers to gain the poorest farmers the opportunity to benefit from new varieties. Pair-wise matrix ranking and direct matrix ranking were used to identify the prioritization order of the farmers 'selection criteria (Tables 3-5).

Several farmers have participated and selected different improved sorghum varieties based on their preference characteristics and agronomic performance. Accordingly, the preferred improved sorghum variety should have high grain yield, bold grain size, brown and white grain color and better resistance to common leaf and panicle diseases (anthracnose and mold). Farmers gave the highest weight to grain yield followed by grain size and color. Similarly, Fentie Molla [23], reported that farmers identified seed color and blast disease reaction as important criteria. Moreover, disease resistance and plant height were also selected by farmers as moderate significance. Based on average grain yield, grain size and disease reaction performance, farmers selected Dibaba and Jiru as the best varieties for their highest yield, bold or large grain size and resistance to different fungal and bacterial diseases. With regard to grain color, most of the farmers preferred ETS2752 and Adelle were selected because of their white attractive color whereas Dibaba and Jiru had brown color which was acceptable from farmers' perspective. However, color alone could not be a good selection criterion in sorghum. Therefore, the varieties of Dibaba and Jiru were preferred depending on the results of field experiment and farmers' evaluation.

Smallholder farmers have evaluated the genotypes by multiplying the relative weight of each criterion by the relative importance based on direct matrix rankings which ranged from 17 to 34. The highest score was provided to Dibaba variety (34) followed by Jiru (32); whereas the least score provided to Shafare [17], due to its low yield and other traits. Moreover, both direct matrix and pair-wise rankings algorithms evaluation give opportunities to farmers to differentiate the merits and demerits of each variety by comparing varieties at a time. According to pair-wise ranking the variety Dibaba preferred five times and ranked first followed by Jiru preferred four and ranked second. Hence, depending on the results of the direct matrix and pair wise ranking evaluation, Dibaba and Jiru were the most preferred ones.

A total of eighty-one farmers were participated to evaluate and select improved sorghum varieties based on their indigenous knowledge of sorghum cultivation. These farmers were preferred improved sorghum varieties using different selection criteria as indicated in table form. Based on the overall farmer's preference, Dibaba and Jiru were ranked first and second respectively and followed by Adelle, Chiro and ETS2752. The integration of plant breeders and farmers used to increase the adoption rate and design a good breeding program for future improvement. As a result, the ultimate goal of plant breeding is to increase yield through targeting farmers' preferred traits and awareness was created about the advantage of improved sorghum varieties as compared to the old varieties which they were growing for targeted communities. Ranking of varieties using individual traits could show clearly the relation between the farmers' preferences and the researcher's view across the varieties. Therefore, the best varieties could be identified using the rank sum method and in addition to farmer's trait preferences, understanding the crops breeding behavior is prerequisite to design a good breeding program.

\section{Summary and conclusion}

Participatory variety selection plays significant a role in the integration between farmers, breeders, policymakers, marketers, processors and consumers. It also allows community engagement in the development of new improved technologies to address the increasing demand for high yielding and 
adaptable varieties. Ethiopia is second the largest sorghum producer in Sub-Saharan Africa. Sorghum is one of the major cereal crops grown in the Ethiopian highlands. Participatory variety selection is the most recent breeding strategy to develop the demand-driven variety particularly farmers preferred traits. However, there are several improved sorghum varieties released without the involvement of smallholder farmers, the millers, the bakers, the target environments, including the level of biotic and abiotic stresses, consumer preference, the processing industry and the production practices of the farmers. Due to these reasons, the improved sorghum technologies are not properly and widely addressed Eastern part of Ethiopia in general, Western Hararghe Zone in particular based on the farmers' preference traits. Hence, the field experiment was conducted to address the biggest problems for the development of superior improved sorghum varieties with farmers' preference traits.

As lack of farmer preferred variety is becoming a serious problem, participatory variety selection is a basic tool in facilitating the adoption rate and enhancing the extension of the improved sorghum technologies. Based on the analyses of variance, mean performance and correlation analyses, the study consistently identified varieties that produced more grain yield than the already existing old varieties that used as a checking addition to this, the pair wise and direct matrix analyses explained that farmers prioritized grain yield, grain size, grain color and reaction to diseases. The farmers selected varieties and grain yield were highly correlated. Therefore, farmers participation was very important in variety evaluation and selection to design breeding methodology for further improvement of sorghum varieties with farmers' end user requirements. Based on quantitative traits and farmers' visual observation at the experimental site was highly and positively correlated. As a result, Dibaba and Jiru were selected for continued cultivation and need to be multiplied and distributed to the farmers for very large-scale production.

Generally, the study concluded that superior performing improved sorghum varieties were successfully identified for future use. The varieties varied one from another in terms of yield and yield related traits, which indicates presence the substantial genetic variation to make selection and recommendation. Several small-holder farmers were participated on varietal selection trial at maturity using both direct-matrix and pair-wise ranking methods of the selection procedure. Based on farmers' preference criteria, the most adapted improved sorghum varieties were effectively identified to address the challenges of both local adaptation and farmers' end user requirements issues. Depending on the results of field experiment and farmers' evaluation, Dibaba and Jiru improved sorghum varieties were the most preferred ones. It also proved that high yielding and earliness of improved varieties were the most important criteria for farmers to choose a new variety, but they indicated they would not totally reject their local varieties because of social considerations. High yielding, earliness, resistance to anthracnose, long smut, and stock borers would be welcomed by farmers. Farmers have been participated in agricultural research to increase awareness toward the philosophy of 'farmer first' and its effectiveness. Participatory variety selection has shown success in identifying superior preferred varieties by farmers in a shorter time in accelerating their adoption and multiplication.

\section{References}

1. FAOSTAT (2019) Food and Agriculture Organization of the United Nations Database of agricultural production. FAO Statistical Databases. Link: https://bit.ly/3ehK090

2. Doggett H, Prasada Rao KE (1995) Sorghum: In Evolution of crop plants (Smartt J and Simmonds NW, eds.). UK: Longman, Harlow.

3. Doggett H (1988) Sorghum Long Mans. 2nd (ed.). Green and Co Itd. London 40-41.

4. Central Statistics Agency (CSA) (2018) Report on Area and Crop Production Forecast for Major Crops. Statistical Bulletin. Addis Ababa, Ethiopia 505: 12 17

5. Reddy BVS, Ramesh S, Reddy PS (2004) Sorghum breeding research at ICRISATgoals, strategies, methods and accomplishments. International Sorghum and Millets Newsletter 45: 5-12. Link: https://bit.ly/3FqAah5

6. Asif M, Ayub M, Tanveer A, Akhtar J (2010) Estimating yield losses and economic threshold level of Parthenium hysterophorus in forage sorghum. Link: https://bit.ly/3z1bGc4

7. Bawazir AA (2009) Genetic analysis for yield and yield components in grain sorghum (Sorghum bicolor L.). Jordan J Agric Food Res 5.

8. Adebo OA, Njobeh PB, Kayitesi E (2018) Fermentation by Lactobacillus fermentum strains (singly and in combination) enhances the properties of ting from two whole grain sorghum types. J Cereal Sci 82: 49-56. Link: https://bit.ly/3qnmJbs

9. Burke JJ, Chen J, Burow G, Mechref Y, Rosenow D, et al. (2013) Leaf dhurrin content is a quantitative measure of the level of pre-and post-flowering drought tolerance in sorghum. Crop Sci 53: 1056-1065. Link: https://bit.ly/3FqA49d

10. Witcombe JR, Joshi KD, Gyawali S, Musa AM, Johansen C, et al. (2005) Participatory plant breeding is better described as highly client-oriented plant breeding. I. Four indicators of client-orientation in plant breeding. Experimen Agric 41. Link: https://bit.ly/3msfEFy

11. Qazi HA, Rao PS, Kashikar A, Suprasanna P, Bhargava S (2014) Alterations in stem sugar content and metabolism in sorghum genotypes subjected to drought stress. Funct Plant Biol 41: 954-962. Link: https://bit.ly/3ySVGIR

12. Probst J, Jones $\mathrm{K}$ (2016) Looking ahead: rural-urban differences in anticipated need for aging-related assistance. Looking ahead: rural-urban differences in anticipated need for aging-related assistance. Link: https://bit.ly/32k5dNm

13. Malandrin V, Dvortsin L (2013) Participatory processes of agro ecological innovation in organic cereal breeding: a case study from Italy. In Book of Proceedings, Fourth International Scientific Symposium Agrosym 719-725. Link: https://bit.ly/3qnykHs

14. Nelson B, Smith S, Bubeck D, Stanek J, Gerke J (2015) Genetic diversity and modern plant breeding. Genetic Diversity Erosion Plants 55-88. Link: https://bit.ly/3epnBXn

15. Bellon MR (2006) Crop research to benefit poor farmers in marginal areas of the developing world: a review of technical challenges and tools. $C A B$ Reviews: Perspectives in Agriculture, Veterinary Science, Nutrition and Natural Resources 1: 1-11. Link: https://bit.ly/32ulxL0

16. Rahman MA, Thant AA, Win M, Tun MS, Moet $P$, et al. (2015) Participatory varietal selection (PVS): a" bottom-up" breeding approach helps rice farmers in the Ayeyarwady Delta, Myanmar. SABRAO J Breed Genet 47: 299-314. Link: https://bit.ly/3suT3Mo

Citation: Begna T, Gichile H (2021) Evaluation and participatory variety selection of improved highland sorghum varieties for smallholder farm at west hararghe zone. J Agric Sc Food Technol 7(3): 374-380. DOI: https://dx.doi.org/10.17352/2455-815X.000135 
17. Ogliari JB, Kist V, Canci A (2013) 5.7 The participatory genetic enhancement of a local maize variety in Brazil. Link: https://bit.ly/3plSOwc

18. Mekbib F (2007) Farmer and formal breeding of sorghum (Sorghum bicolor (L.) Moench) and the implications for integrated plant breeding. Euphytica 152: 163-176. Link: https://bit.ly/3su7mk9

19. Adugna A (2007) Assessment of yield stability in sorghum. Afr Crop Sci J 15 21. Link: https://bit.ly/3yQhjcZ

20. IBPGR and ICRISAT (1993) Descriptors for sorghum [sorghum bicolor (L.) Moench]. International Board for plant genetic Resources, Rome, Italy; International Crops Research Institute for the Semi -Arid Tropics, Patancheru, India. Link: https://bit.ly/3Hns6yv
21. Institutes Inc (2016) SAS /STAT users guide. Version $9.4,4^{\text {th }}$ edition. Cat, NC Link: https://bit.ly/3FrlE8M

22. Lelo F, Ayieko J, Makenzi P, Muhia D, Muiriri H, et al. (1995) Field Handbook for Participatory Rural Appraisal Practioners. The PRA Programme, Egerton University, Njoro, Kenya 11. Link: https://bit.ly/3FtagJF

23. Fentie M (2012) Participatory evaluation and selection of improved finge millet varieties in north western Ethiopia. Int Res J Plant Sci 3: 141-146. Link: https://bit.ly/3qjizBA
Discover a bigger Impact and Visibility of your article publication with Peertechz Publications

\section{Highlights}

* Signatory publisher of ORCID

* Signatory Publisher of DORA (San Francisco Declaration on Research Assessment)

* Articles archived in worlds' renowned service providers such as Portico, CNKI, AGRIS, TDNet, Base (Bielefeld University Library), CrossRef, Scilit, J-Gate etc.

* Journals indexed in ICMJE, SHERPA/ROMEO, Google Scholar etc.

- OAI-PMH (Open Archives Initiative Protocol for Metadata Harvesting)

* Dedicated Editorial Board for every journal

* Accurate and rapid peer-review process

* Increased citations of published articles through promotions

- Reduced timeline for article publication

Submit your articles and experience a new surge in publication services (https://www.peertechz.com/submission).

Peertechz journals wishes everlasting success in your every endeavours. 